\title{
The effects of cavity disinfection on the nanoleakage of compomer restorations: an in vitro study*
}

\begin{abstract}
Purpose
Cavity disinfection, in addition to routine caries removal methods, is recommended to eliminate the microorganisms. The aim of this study was to compare the effect of various systems Er,Cr:YSGG lasers, diode lasers and FotoSan and agents Corsodyl; Cervitec and Cervitec Plus and Fluor Protector-on the nanoleakage of compomer restorations when used for cavity disinfection.
\end{abstract}

\section{Materials and Methods}

A total of 40 intact human deciduous molar teeth containing BlackV cavities $(3 \times 2 \times 1.5$ $\mathrm{mm}$ ) on the buccal and lingual surfaces parallel to the cementoenamel junction were randomly divided into 8 groups according to the cavity disinfection methods. The antibacterial agents and systems were applied according to the manufacturer's instructions. Restorations were completed using a compomer. The restored teeth were then subjected to thermocycling for 500 cycles in a water bath at $5^{\circ} \mathrm{C}$ and $55^{\circ} \mathrm{C}$ with a dwell time of 30 seconds. After the thermocycling procedures, 1-mm sticks were obtained from the center of each cavity to prepare for the nanoleakage test. After the teeth were sectioned, they were immersed in $50 \mathrm{wt} \%$ ammoniacal silver nitrate solution for 24 hours and dipped in photo-developing solutions for 8 hours with fluorescent light irradiation. The samples were examined under a scanning electron microscope (SEM). The non-parametric Kruskal-Wallis and Mann-Whitney $U$ test $(p<0.05)$ were applied.

\section{Results}

The Er,Cr:YSGG laser group showed significantly less nanoleakage than all of the tested groups $(p<0.01)$. The diode laser, Fluor protector and FotoSan groups showed similar nanoleakage to that of the control group $(p>0.05)$. The Corsodyl $(p<0.01)$ and Cervitec $(p<0.001)$ groups showed significantly higher nanoleakage than the control group.

\section{Conclusion}

$\mathrm{Er}, \mathrm{Cr}$ :YSGG laser irradiation which showed lower nanoleakage scores from either control or tested groups can be recommended for cavity disinfection Additionally, a diode laser and FotoSan, which have antibacterial effects and no negative effect on leakage, can be used for cavity disinfection.

Keywords: Er,Cr:YSGG laser; Diode laser; FotoSan; Antibacterial agents; Nanoleakage

\section{Introduction}

Traditional restorative dentistry aims to remove all infected tooth structures and obturate the area with biocompatible filling materials (1). However, none of the currently used caries removal methods eliminate all of the microorganisms in the cavities consistently (2). Several studies have shown the existence of bacteria in dentin even after using caries detector dyes $(3,4)$. Researchers have proved that fermentative microorganisms remained viable under non- antiseptic restorations for as long as 139 days (5).

\author{
Ipek Arslan' ${ }^{1}$, \\ Ozgul Baygin² (D), \\ Tamer Tuzuner ${ }^{2}$ (D), \\ Fatih Erdemir ${ }^{3}$ (D), \\ Aykut Canakci $^{3}$ (D), \\ Fatih Mehmet Korkmaz ${ }^{4}$
}

Presented at: Presented in 22. Turkish Pediatric Dentistry Association Scientific Congress, Girne, Cyprus; November

ORCID IDs of the authors: I.A. 0000-0002-8648-3554, O.B. 0000-0003-2220-7654; T.T. 0000-0001-5817-5928; F.E. $0000000204499801 ;$ A.C. 0000000152446467 F.M.K. 0000-0001-9324-2014

${ }^{1}$ Recep Tayyip Erdoğan University, Faculty of Dentistry, Department of Pediatric Dentistry, Rize, Turkey

${ }^{2}$ Karadeniz Technical University, Faculty of Dentistry, Department of Pediatric Dentistry, Trabzon, Turkey

${ }^{3}$ Karadeniz Technical University, Faculty of Engineering, Department of Metallurgical and Materials Engineering Trabzon, Turkey

${ }^{4}$ Karadeniz Technical University, Faculty of Dentistry, Department of Prosthodontic, Trabzon, Turkey Corresponding Author: Ipek Arslan E-mail: sareipekarslan@gmail.com Received: 13 May 2019 Revised: 17 September 2019 Accepted: 27 September 2019

DOI: 10.26650/eor.20200053 
Thus, cavity disinfection, in addition to routine caries removal methods, is recommended to eliminate the microorganisms and reduce potential secondary caries, pulp sensitivity and pulp inflammation before restoring the cavities $(6,7)$.

The treatments of carious lesions has been changing as the knowledge about the caries process has increased (8). Some authors have advised that new approaches should remove only infected dentin and provide an opportunity for the affected dentin to undergo remineralization $(8,9)$. The main problem with this approach is the remaining cariogenic bacteria. Thus, cavity disinfection has gained importance with new approaches $(8,10)$.

In the literature regarding cavity disinfection, various systems and agents are suggested. Understanding the disinfection mechanisms and their effects on the sealing ability of restorative material is essential in the selection of disinfection methods (11).

Chlorhexidine ( $\mathrm{CHX})$ is a commonly used cavity disinfection agent in dental procedures. Its disinfection effect occurs upon its binding to the amino acids in microorganisms, and its effects can continue for several hours. Due to these properties, CHX is an excellent antibacterial agent $(12,13)$. However, in the literature, there is disagreement concerning the effects of chlorhexidine on the sealing ability of resin restorative materials. Some researchers have argued that chlorhexidine has no adverse effects on bond strength and leakage $(14,15)$. Conversely, some studies have reported that chlorhexidine increases leakage scores $(16,17)$.

Currently, combinations of chlorhexidine with other antibacterial agents-e.g., fluoride or thymol-are commercially available. In the present study, Corsodyl gel containing $1 \% \mathrm{CHX}$ digluconate, Cervitec gel (combination of $0.2 \%$ $\mathrm{CHX}$ digluconate and sodium fluoride gel) and Cervitec Plus Varnish (combination of 1\% CHX diacetate and 1\% Thymol) were used. Many studies have reported that these combinations showed less antibacterial activity than $\mathrm{CHX}(18,19)$. Wallman et al. (19) reported that $\mathrm{CHX}$ gel was more effective in reducing MS in saliva compared with Cervitec. The other study showed that $\mathrm{CHX}$-containing dentifrice was more effective in reducing MS in saliva compared with Cervitec (19).

Fluoride is the most popular anticaries agent in dentistry. Its antibacterial activity has been demonstrated many times (20-22). Fluoride is not designed specifically for cavity disinfection, but some properties of fluoride such as its ability to inhibit active growth of cariogenic bacteria, remineralize the affected dentin, and increase the microhardness of dentin $(8,23)$ were thought to make it usable as a cavity disinfectant. Some recent studies have tested it for cavity disinfection $(8,24)$.

Photoactivated disinfection (PAD), also known as antimicrobial photodynamic therapy, is a disinfection method that can be used in both restorative and endodontic treatment to eliminate microorganisms. Its disinfection principle is based on a photosensitiser, which is irradiated by a specific wavelength of light (25). After irradiation, singlet oxygen is produced that causes bacterial cell wall rupture and faster antibacterial effects (26). Previous studies have demonstrated the reduction by $95-99.9 \%$ of the viable cell count with PAD $(27,28)$.

Laser therapy is a disinfection system that is effective against oral bacteria, associated or not with a photosensi- tiser. The antibacterial action of a laser is related to its thermal effects and photodisruption (29). Despite its well-known antibacterial action, studies concerning the use of lasers for cavity disinfection are limited. One previous study proved its effectiveness against caries-related bacteria (30).

The ideal cavity disinfectant should provide both strong antimicrobial action and not interfere with the sealing ability of restorative materials (31). When the sealing ability is disrupted, marginal leakage may occur. The occurrence of leakage between restorative material and teeth may decrease the longevity of restoration (32). Nanoleakage is described as the diffusion of nanoscale ions or molecules in the hybrid layer of the restoration (33). Silver nitrate (AgNO3), which is detectable by both SEM and TEM, is used to evaluate nanoleakage (34).

The aim of this study was to compare the effect of various systems-Er,Cr:YSGG lasers, diode lasers and FotoSan, which is a PAD system-and agents-Corsodyl; Cervitec and Cervitec Plus, which contains $\mathrm{CHX}$ in their combination; and Fluor Protector-on the nanoleakage of compomer restorations when used for cavity disinfection. The null hypotheses tested were as follows: 1) The systems and agents that were used in the study would have no effect on nanoleakage; 2) nanoleakage would not differ between the systems or agents.

\section{Materials and Methods}

\section{Specimen preparation}

Ethical approval of the present study was obtained from the Ethics Committee of Karadeniz Technical University, Faculty of Medicine (Protocol \# 2015/149). A total of 40 intact human deciduous molar teeth extracted for exfoliation or orthodontic reasons were collected and cleaned with pumice. The teeth were stored in $0.5 \%$ Chloramine T aqueous solution following the extraction. Standardized class $\mathrm{V}$ cavities $(3 \times 2 \times 1.5 \mathrm{~mm})$ were prepared on the facial and lingual/palatinal surfaces of each tooth with a diamond bur (Diatech Swiss Dental Instruments, Switzerland; 881-012-8 $\mathrm{ml}$ ), parallel to the cementoenamel junction. Next, the teeth were randomly divided into eight experimental groups of 10 teeth, each according to cavity disinfection method. The antibacterial agents and systems were applied according to the manufacturer's instructions (Table 1).

\section{Restoration}

After disinfection, all samples were restored with a compomer (Dyract eXtra, Dentsply, Germany) according to the manufacturer's instructions. Prime\&Bond NT (Dentsply, Germany) were used as bonding agent. Finishing was achieved by using flexible polishing discs. The restored teeth were then subjected to thermocycling for 500 cycles in a water bath at $5^{\circ} \mathrm{C}$ and $55^{\circ} \mathrm{C}$ with a dwell time of 30 seconds. After the thermocycling procedures, 1-mm sticks were obtained from the center of each cavity to prepare for the nanoleakage test.

\section{Preparation for nanoleakage test}

Two layers of nail varnishes were applied to sticks up to 1 $\mathrm{mm}$ from the restoration margins. The specimens were then 
Table 1. Agents and systems used for cavity disinfection and application forms

\begin{tabular}{|c|c|}
\hline Agents-Systems & Application Forms \\
\hline Group 1: Control & - No disinfection process applied. \\
\hline $\begin{array}{l}\text { Group 2: Corsodyl } \\
\text { (GlaxoSmithKline USA) }\end{array}$ & $\begin{array}{l}\text { - } 1 \% \text { CHX Digluconate gel was applied to the dentin for } 1 \text { minute } \\
\text { - Excess gel was removed from the cavity with a clean cotton pellet }\end{array}$ \\
\hline $\begin{array}{l}\text { Group 3: Cervitec } \\
\text { Gel (Ivoclar, Schaan, } \\
\text { Liechtenstein Germany) }\end{array}$ & $\begin{array}{l}\text { - A combination of } 0.2 \% \text { CHX Digluconate and Sodium Fluoride gel was applied to the dentin for } 2 \\
\text { minutes. }\end{array}$ \\
\hline $\begin{array}{l}\text { Group 4: Cervitec } \\
\text { Plus (Ivoclar, Schaan, } \\
\text { Liechtenstein) }\end{array}$ & $\begin{array}{l}\text { - A combination of } 1 \% \text { CHX Diacetate and } 1 \% \text { thymol varnish (Ivoclar Vivadent) was applied to the } \\
\text { dentin for } 2 \text { minutes. }\end{array}$ \\
\hline $\begin{array}{l}\text { Group 5: Fluor Protector } \\
\text { (Ivoclar, Schaan, Liechtenstein) }\end{array}$ & - A 1\% difluorosilane varnish was applied to dentin for 1 minute. \\
\hline $\begin{array}{l}\text { Group 6: PAD (FotoSan, CMS } \\
\text { Dental, Denmark) }\end{array}$ & $\begin{array}{l}\text { - A fotosensitiser containing } 0.01 \% \text { toluidine blue was applied to the dentin. } \\
\text { - The teeth were irradiated with red light }(660 \mathrm{~nm} \text { wavelength and } 100 \mathrm{~mW}\end{array}$ \\
\hline $\begin{array}{l}\text { Group 7: Diode laser (Biolase, } \\
\text { San Clemente, CA) }\end{array}$ & $\begin{array}{l}\text { - The dentin surfaces were irradiated with a diode laser with a wavelengths of } 940 \mathrm{~nm}, 1-\mathrm{W} \text { power } \\
\text { output, and } 20-\mathrm{Hz} \text { frequency. } \\
\text { - A sapphire tip, } 600 \mu \mathrm{m} \text { in diameter and } 6 \mathrm{~mm} \text { in length was used to deliver the laser light. }\end{array}$ \\
\hline $\begin{array}{l}\text { Group 8: Er:Cr;YSGG laser } \\
\text { (Waterlase MD; Biolase, San } \\
\text { Clemente, CA) }\end{array}$ & $\begin{array}{l}\text { - The dentin surfaces were irradiated with an Er,Cr:YSGG laser with a wavelength of } 2780 \mathrm{~nm}, 1-\mathrm{W} \text { power } \\
\text { output, and } 20-\mathrm{Hz} \text { frequency. } \\
\text { - A sapphire tip, } 600 \mu \mathrm{m} \text { in diameter and } 6 \mathrm{~mm} \text { in length, was used to deliver }\end{array}$ \\
\hline
\end{tabular}

immersed in $50 \mathrm{wt} \% \mathrm{AgNO} 3$ solution in the dark chamber according to Tay et al. (35) for 24 hours and then were rinsed with running water for 5 minutes, dipped in photodeveloping solutions for 8 hours with fluorescent light irradiation to reduce the silver or diamine silver ions to metallic silver (36) and again washed with running water for 5 minutes.

\section{SEM/EDX and Elemental Mapping analyses}

The sticks were embedded into acrylic resin prior to polishing. The specimens were polished with descending grits of silicone carbide papers (600, 1200 and 2500) and diamond polishing paste then conditioned with $5 \%$ phosphoric acid for $5 \mathrm{sec}$ and immersed in ethanol solution (70\%) for $10 \mathrm{sec}$. They were coated with a thin layer of gold (sputtering) and analyzed using SEM in the backscattered mode. Quantitative analyses of AgNO3 uptake into the hybrid layer were performed as a percentage with EDX analyses.
Elemental mapping of the samples was performed using SEM-EPMA. The elements in the samples were marked with different colors.

\section{Statistical analysis}

Statistical analyses were performed with SPSS 15.0 for Windows (SPSS Inc., Chicago, III, USA). Shapiro-Wilks test was used to evaluate the distribution of the data. The Non-parametric Kruskal-Wallis and Mann-Whitney $U$ tests $(p<0.05)$ were applied. The group that caused the difference was identified with the Mann Whitney $U$ test.

\section{Results}

AgNO3 accumulations in all samples were seen in SEM images, EDX and elemental mapping analyses. In some SEM images, cracks were visible in the materials but this was not

Table 2. The effect of the agents and systems used in the study on the nanoleakage values of compomer restorations

\begin{tabular}{|c|c|c|c|c|c|}
\hline & $\begin{array}{l}\text { Ag (\%) } \\
\text { Mean Value }\end{array}$ & $\begin{array}{l}\text { Standard } \\
\text { Deviatio }\end{array}$ & $\begin{array}{l}\text { Ag (\%) } \\
\text { Max Value }\end{array}$ & $\begin{array}{l}\text { Ag (\%) } \\
\text { Min Value }\end{array}$ & $\begin{array}{l}\text { Comparison } \\
\text { with control }\end{array}$ \\
\hline Group 1 & $42.7^{\mathrm{b}, \mathrm{c}}$ & 5.75 & 53 & 35 & ----- \\
\hline Group 2 & $73.4^{\mathrm{a}, \mathrm{c}}$ & 11.06 & 80 & 45 & 0,000 \\
\hline Group 3 & $58.1^{a, b, c, d}$ & 10.35 & 67 & 42 & 0,001 \\
\hline Group 4 & $49.5^{\mathrm{b}, \mathrm{c}}$ & 14.21 & 67 & 29 & 0,126 \\
\hline Group 5 & $48.0^{b, c}$ & 15.01 & 67 & 22 & 0,286 \\
\hline Group 6 & $37.9^{b, c}$ & 12.14 & 54 & 21 & 0,692 \\
\hline Group 7 & $43.0^{b, c}$ & 4.05 & 53 & 39 & 0,378 \\
\hline Group 8 & $20.5^{a, b}$ & 5.19 & 26 & 15 & 0,000 \\
\hline \multicolumn{6}{|c|}{ 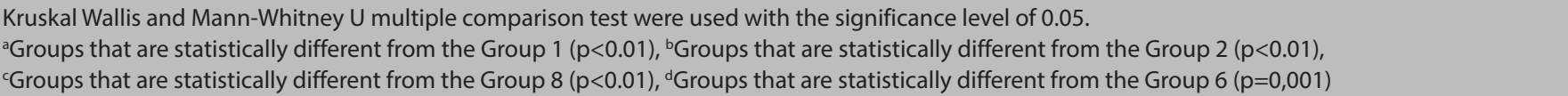 } \\
\hline
\end{tabular}


taken into consideration as an important result because the samples were subjected to vacuum conditions. SEM images and elemental mapping showed that $\mathrm{AgNO} 3$ uptake were generally noted at the base of the hybrid layer.

The resin-dentin interfaces in the eight groups were analysed with SEM-EDX; AgNO3 deposition was observed. Eight groups were analysed using line scanning: $\mathrm{Si}, \mathrm{C}$, and
Ca element peaks were detected. The means, minimum and maximum uptake values (\%) of AgNO3, standard deviation and $p$ values compared with the control group are shown in Table 2. The Corsodyl $(p<0.01)$ and Cervitec $(p<0.001)$ groups showed significantly higher nanoleakage than the control group. The Er,Cr:YSGG laser group showed significantly less nanoleakage than the control group $(p<0.001)$.
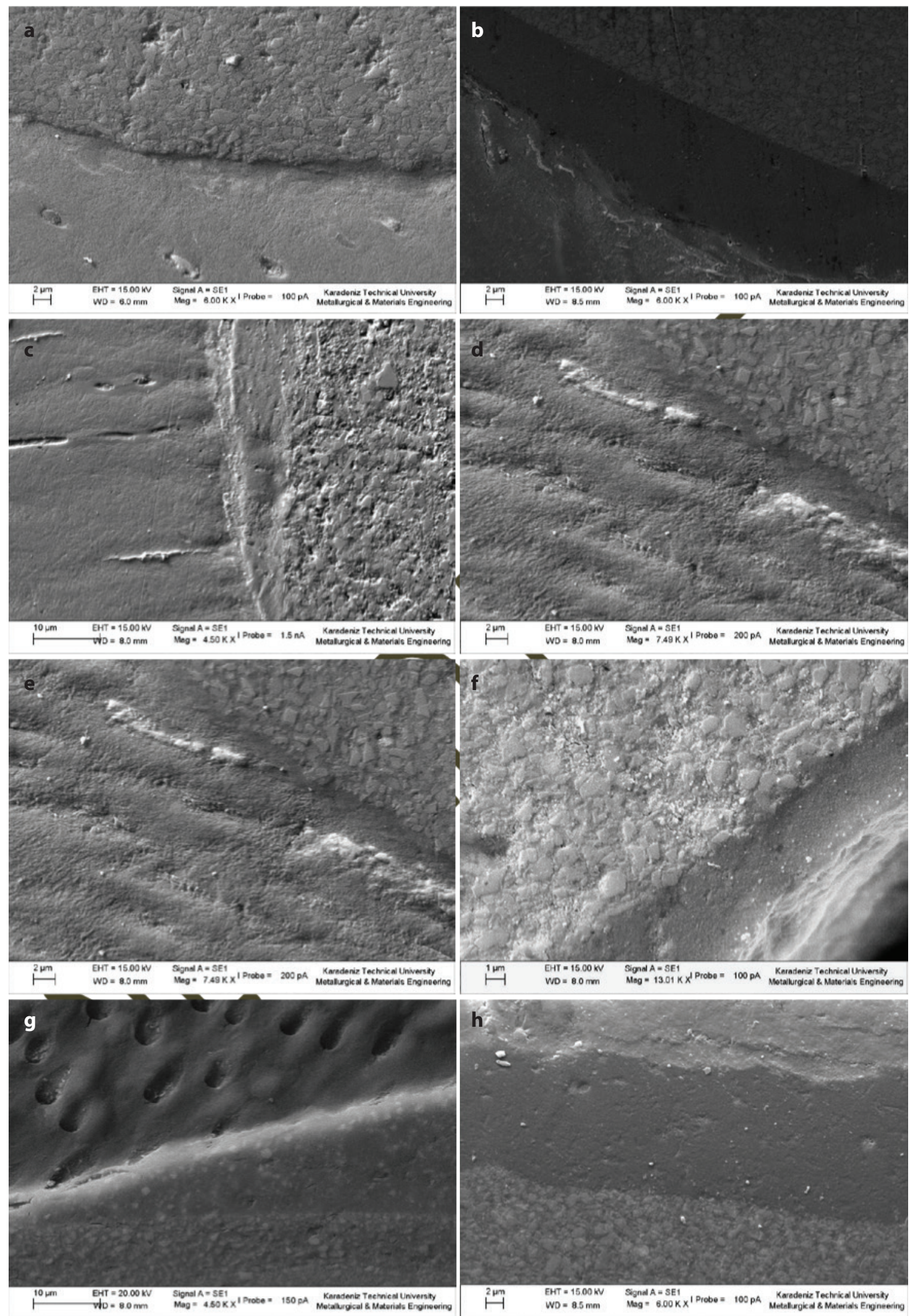

Figure 1. Representative backscattered SEM images of groups. a: Control group, b: Corsodyl group, c: Cervitec group, d: Cervitec Plus group, e: Fluor Protector Group, f: FotoSan group, g: Diode Laser group, $h$ : Er, Cr:YSGG Laser group. 
The Cervitec Plus, Flour Protector, FotoSan and diode laser groups showed similar nanoleakage results to the control group $(p>0,1)$. The Corsodyl group showed higher nanoleakage than all the tested groups $(p<0.01)$. The Er,Cr:YSGG laser group showed significantly less nanoleakage than all the tested groups $(p<0.01)$. The SEM images, as well as the findings on elemental analysis and SEM-EDX analysis of the groups, are given in Figures 1-3.
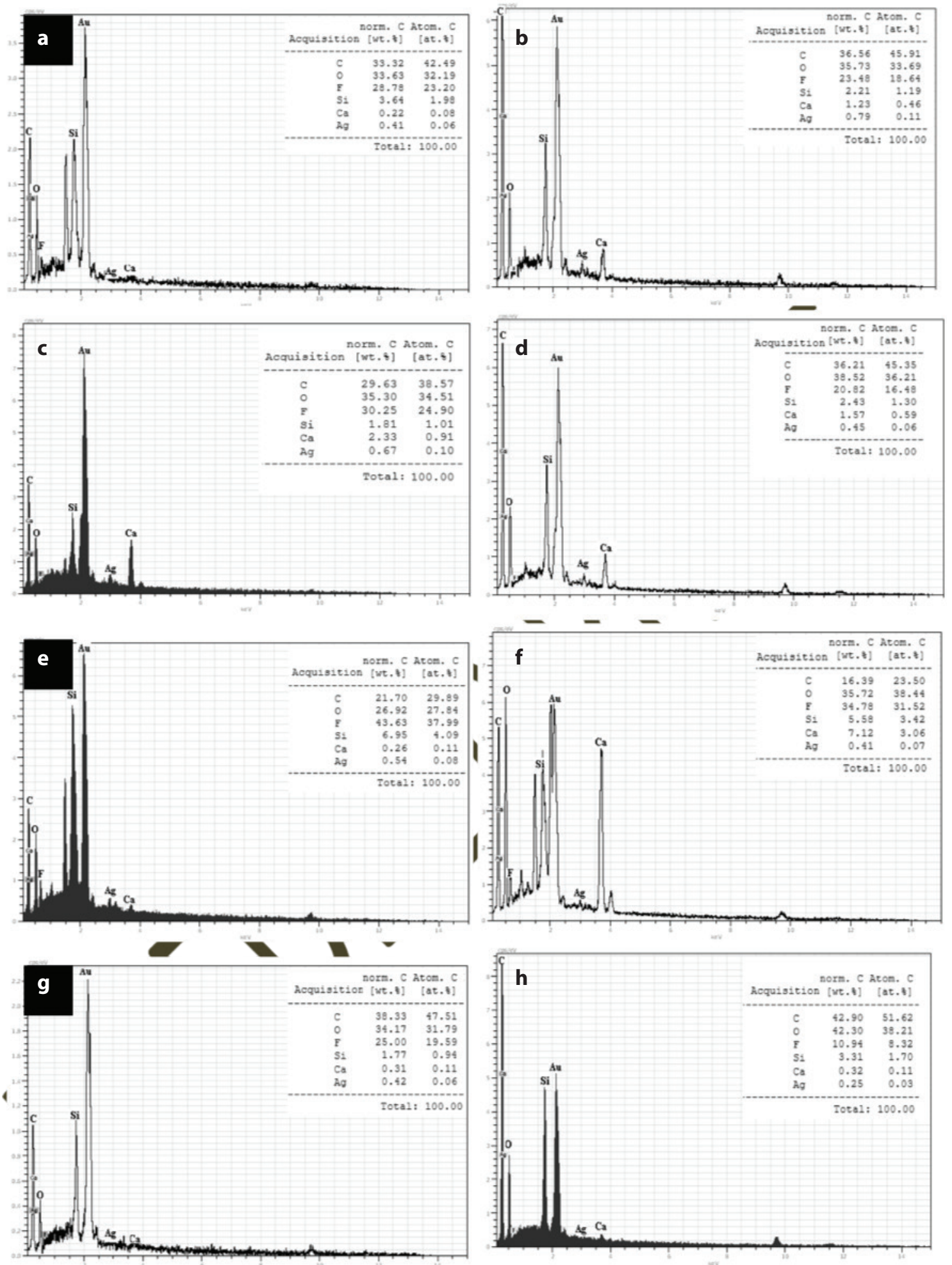

Figure 2. The Ag ion uptake percentages of groups. a: Control group, b: Corsodyl group, c: Cervitec group, d: Cervitec Plus group, e: Fluor Protector Group, f: FotoSan group, g: Diode Laser group, h: Er, Cr:YSGG Laser group. 


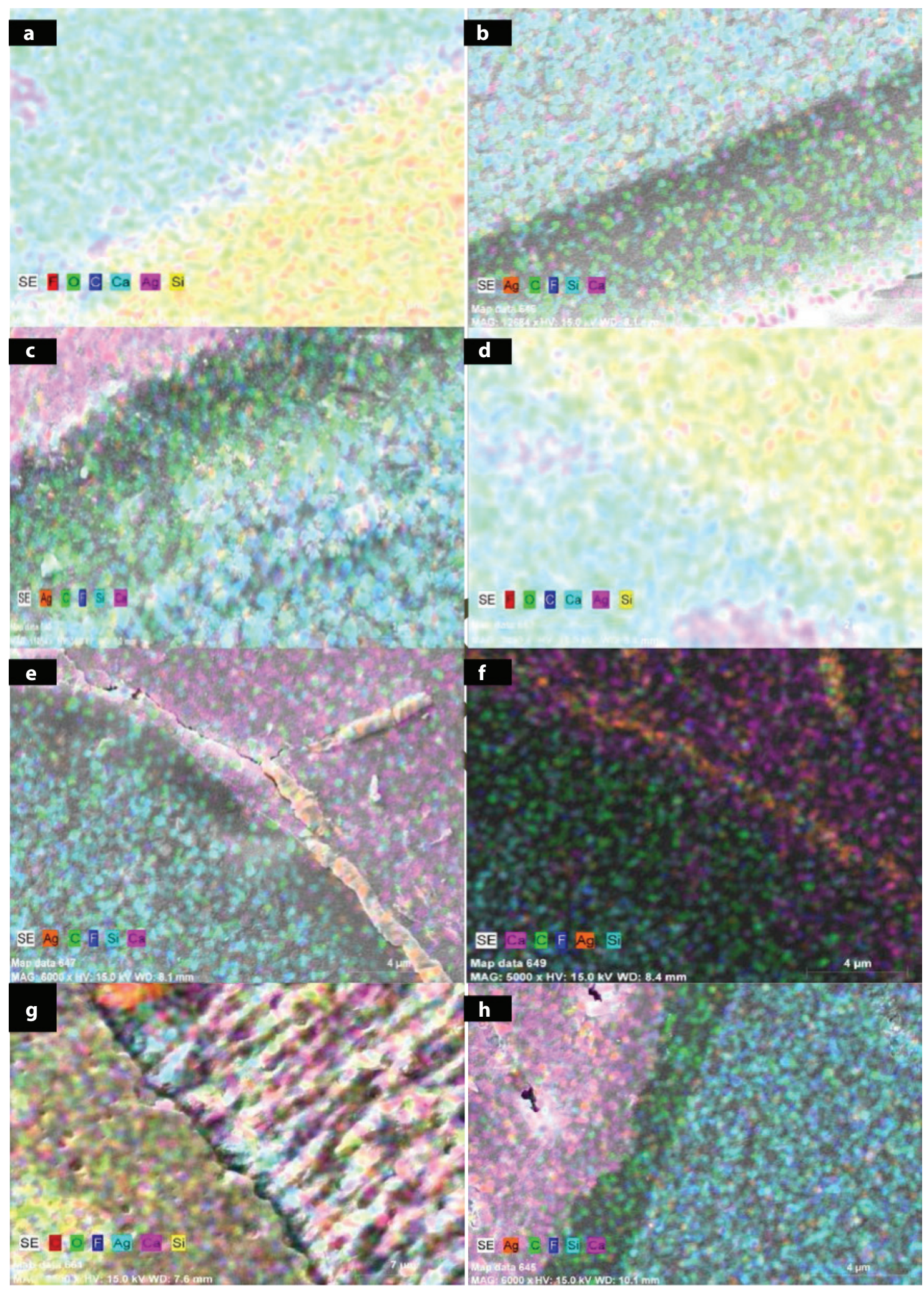

Figure 3. Distrubition of the ions were shown with mapping. Colours shown at the bottom of the SEM images represent the ions written in. a: Control group, b: Corsodyl group, c: Cervitec group, d:Cervitec Plus group, e: Fluor Protector Group, f: FotoSan group, g:Diode Laser group, h:Er, Cr:YSGG Laser group.

with the sealing ability (16). Because of these reasons; with the aim of comparing the effect of various systems; $\mathrm{Er}, \mathrm{Cr}: \mathrm{YS}$ GG lasers, diode lasers and FotoSan, which is a PAD system and agents; Corsodyl Cervitec and Cervitec Plus, which contains CHX in their combination; and Fluor Protector on the nanoleakage of compomer restorations when used for cavity disinfection, the present study was designed.
Leakages have been mostly investigated at the micro scale (39). However, the diameter of the stained particles used in microleakage studies was larger than that of the bacteria; thus, the leakage was not detected accurately. So, researchers have searched for new methods (40). Nanoleakage refers to the nanosize leakage that occurs around collagen fibrils in the hybrid layer. In nanoleakage studies, staining is per- 
formed using AgNO3 solution. The AgNO3 solution particles are approximately $0.59 \mathrm{~nm}$ in size. The sizes of the bacteria that live in the mouth vary between 0.5 and $1 \mathrm{~nm}$. Thus, AgNO3 is considered a suitable staining solution for leakage studies (41). Until now, the effects of cavity disinfection on nanoleakage have not been investigated. All the studies conducted previously were microleakage studies.

Currently, various cavity disinfectants have been used and include chlorhexidine, fluoride gels, sodium hypochloride, benzalkonium-based solutions, propolis and Aloe vera $(42,43)$. Technological devices like lasers or PAD systems may be alternative procedures for cavity disinfection $(27,30)$.

Chlorhexidine is the accepted gold standard antibacterial agent that is commonly studied when used as a cavity disinfectant (17). Speculation exists concerning the effects of chlorhexidine on the sealing ability of resin-restorative materials. Some researchers have found that chlorhexidine does not have an adverse effect on the bond strength $(14,15)$. On the other hand, studies have demonstrated controversial results that chlorhexidine increases leakage scores $(16,17)$. The studies that found chlorhexidine increased leakage scores used self-etched adhesive systems. This situation can be attributed to negative interactions between chlorhexidine and the self-etched adhesive systems (17).

In the present study, an increased nanoleakage score was found in the chlorhexidine group. This result also concurs with studies using the self-etched adhesive system $(11,17)$ such as PrimeBond NT, which was used in this study.

The combinations of chlorhexidine with other antibacterial agents, such as fluoride or thymol, are commercially available. In the present study, Cervitec gel (chlorhexidine digluconate and sodium fluoride) and Cervitec Plus varnish (chlorhexidine diacetate and thymol) were used. Although the Cervitec groups showed significantly higher nanoleakage than the control group $(p<0.001)$, the Cervitec Plus group showed similar nanoleakage results to the control group ( $p>0.1)$. This situation could be explained with the concentration differences between the Cervitec and Cervitec Plus groups. Cervitec has a gel form, but Cervitec Plus has a varnish form.

The studies concerning the effect of fluoride on leakage are limited, and in most of the studies, fluoride was used as a desensitiser or demineralising agent $(44,45)$. Selveraj et al. (45) used silver diamine fluoride/potassium iodide (SDF) for dentin pretreatment. They reported that SDF minimized the leakage score. In the present study, the Fluor Protector group showed similar nanoleakage scores to the control group. This can be explained by the differences between the fluoride contents. In another study, Nystrom et al. (46) applied $0.71 \%$ tin fluoride to class $\mathrm{V}$ restorations that comprised 50\% cement and 50\% enamel and restored the teeth with a composite by using a total etch adhesive. No significant differences were detected compared with the control group when the microleakage values were examined. No significant differences were detected between the Fluor Protector that contained fluoride and the control group in present study $(p=0.286)$. However, higher nanoleakage values were detected compared with the Cervitec Gel and control groups ( $p=0.001)$. The cause might be fact that Cervitec were in gel forms, and the Fluor Protector was in a varnish form. Additionally, many differences were found in their contents.
Penetration into dentin tubules is one of the important factors for the selection of cavity disinfection methods. Chemical agents can penetrate only up to $130 \mu \mathrm{m}$ into dentin, although bacterial penetration is $1100 \mu \mathrm{m}$. (47) Thus, lasers and PAD with high penetration capabilities gain importance $(48,49)$. Odor et al. (50) gave a possible explanation about the penetration of laser beams to dentin. According to their explanations, enamel and dentin are capable of acting as a light collecting and transmitting device. Therefore, emitted laser light to the deeper layers of dentin can be actualized (48).

Although PAD has strong antibacterial efficacy, limited data are available concerning its effects on marginal leakage. Oskee et al. (51) used a PAD, Nd:YAG and diode laser for cavity disinfection. They declared that diode lasers and PAD had no detrimental effects on marginal leakage. In another study, no adverse effects of PAD on marginal leakage were found, in accordance with the present study, which used FotoSan as a PAD system (52).

Laser irradiation on dental hard tissues has been widely studied in dentistry $(8,12)$. Several advantages, such as the creation of an acid-resistant surface, antibacterial activity and enhanced bonding capacity, were shown in previous studies $(30,53)$. In the present study Diode and Er,Cr:YSGG laser were used. The limited studies were found about the diode laser usage for cavity disinfection $(51,54)$. They found that diose laser had no adverse effect on marginal leakage parallel to the results of the present study. After Er:YAG laser treatment, a honeycomb pattern similar to that following phosphoric acid application was observed (55). An increased bonding capacity can be explained with this pattern. It was reported in a previous study that $\mathrm{Er}, \mathrm{Cr}$ :YSGG laser etching does not eliminate the need for acid etching (56). In the present study, a self-etched bonding system was used; thus, no additional acid etching was used. In the present study, decreased nanoleakage scores after Er,Cr:YSGG laser irradiation can be explained by the honeycomb pattern detected following phosphoric acid application; thus, the sealing ability of the restoration material may increase. Consistent with the results of this study, Baygin et al. (53) found decreased microleakage scores after Er,Cr:YSGG laser irradiation.

According to the results of the present study, the first null hypothesis, 'the systems and agents that were used in the study would have no effect on nanoleakage' was rejected. Corsodyl and Cervitec usage increased and Er,Cr:YSGG laser usage decreased the nanoleakage scores compared with the control group. Also, the second null hypothesis, 'nanoleakage would not differ between the systems or agents' was rejected. The Corsodyl use showed higher nanoleakage than in all the tested groups and the Er,Cr:YSGG laser group showed significantly less nanoleakage than all the tested groups.

\section{Conclusion}

Under the limitations of this study, Er,Cr:YSGG laser irradiation, which showed lower nanoleakage scores than either the control or tested groups, can be recommended for cavity disinfection. Also Diode laser, FotoSan and Fluor Protector which have no adverse effect on nanoleakage scores can be alternative system for cavity disinfection. 
Türkçe Öz: Kavite dezenfeksiyonunun kompomer restorasyonların nanosızıntısına etkileri: taramalı elektron mikroskobu ve enerji dağılımIı x-ray analizi. Amaç: Rutin çürük uzaklaştırma yöntemlerine ek olarak kavite dezenfeksiyonu mikroorganizmaların eliminasyonu için önerilmektedir. Bu çalışmanın amacı farklı sistemlerin; Er,Cr:YSGG lazer, diod lazer, FotoSan ve ajanların; Corsodyl, Cervitec, Cervitec Plus, Fluor Protector kavite dezenfeksiyonu amacıla kullanımında kompomer restorasyonların nanosızıntısına etkilerinin incelenmesidir. Gereç ve yöntem: Bukkal ve lingual yüzlerinde mine sement sınırına paralel sınıf $V$ kaviteler $(3 \times 2 \times 1.5 \mathrm{~mm})$ bulunan 40 adet insan süt azı dişi kavite dezenfeksiyon yöntemine göre 8 gruba ayrıldı. Antibakteriyel ajan ve sistemler üretici firmaların önerileri doğrultusunda uygulandı. Tüm örnekler kompomer dolgu materyali ile restore edildi. Restore edilen dişlere 30 saniye $5^{\circ} \mathrm{C}-55^{\circ} \mathrm{C}$ su banyosunda 500 tur termal siklus uygulandı. Termal siklus işlemlerinden sonra, nanosızıntı testleri için herbir kavitenin orta hattından 1 mm'lik kesit alındı. Örnekler bölündükten sonra \%50'lik amonoikal gümüş nitrat solüsyonunda 24 saat, florosan ışık altında fotoğraf solüsyonunda 8 saat bekletildi. Örnekler SEM ile incelendi. İstatistiksel analizlerde non parametrik Kruskal Wallis ve Mann Whitney U Test'leri uygulandı. Bulgular: Er,Cr:YSGG lazer grubunda diğer gruplara göre anlamlı derecede daha az nanosızıntı görüldü $(p<0.01)$. Diod lazer, Fluor Protector ve Fotosan grupları kontrol grubuna göre benzer nanosızıntı skorları gösterdiği bulundu $(p>0.05)$. Corsodyl $(p<0.01)$ ve Cervitec $(p<0.001)$ gruplarında ise nanosızıntı miktarı kontrol grubuna göre daha yüksek olduğu tespit edildi. Sonuç: Antibakteriyel etkinliği bulunan ve hem kontrol hem de test gruplarına göre daha düşük nanosızıntı değerleri gösteren Er,Cr:YSGG lazer kavite dezenfeksiyonunda önerilebilir. Ayrıca antibakteriyel etkinliği bulunan ve sızıntıyı etkilemeyen diod lazer ve FotoSan da kavite dezenfeksiyonunda önerilebilecek yöntemler arasında yer alabilir. Anahtar kelimeler: Er,Cr:YSGG Lazer; Diod Lazer; FotoSan; Antibakteriyal Ajan; Nanosızıntı.

Ethics Committee Approval: Ethical approval of the present study was obtained from the Ethics Committee of Karadeniz Technical University, Faculty of Medicine (Protocol \# 2015/149).

Informed Consent: The informed consents were provided by the participants.

Peer-review: Externally peer-reviewed.

Author contributions: IA and $O B$ designed the study. IA, FE and $A C$ participated in generating the data for the study. IA and OB participated in gathering the data for the study. TT and FMK participated in the analysis of the data. IA wrote the majority of the original draft of the paper. IA and OB participated in writing the paper. All authors approved the final version of this paper.

Conflict of Interest: The authors had no conflict of interest to declare.

Financial Disclosure: The authors declared no financial support.

\section{References}

1. Anderson $\mathrm{MH}$, Bales DJ, Omnell KA. Modern management of dental-caries - the cutting edge is not the dental bur. J Am Dent Assoc 1993;124(6):37-44. [CrossRef]

2. Boston DW, Graver HT. Histobacteriological analysis of acid red-dye stainable dentin found beneath intact amalgam restorations. Oper Dent 1994;19(2):65-9.

3. El-Housseiny AA, Jamjoum $H$. The effect of caries detector dyes and a cavity cleansing agent on composite resin bonding to enamel and dentin. J Clin Pediatr Dent 2000;25(1):57- 63. [CrossRef]

4. Meiers JC, Kresin JC. Cavity disinfectants and dentin bonding. Oper Dent 1996;21(4):153- 9.

5. Schouboe T, MacDonald, J.B. Prolonged viability of organisms sealed in dental caries. Arch Oral Biol 1962;7:5256. [CrossRef]
6. Magni E, Ferrari M, Hickel R, Huth KC, Ilie N. Effect of ozone gas application on the mechanical properties of dental adhesives bonded to dentin. Dent Mater 2008;24(10):142834. [CrossRef]

7. Ersin NK, Candan, U., Aykut, A., Eronat, C., Belli, S. No adverse effect to bonding following caries disinfection with chlorhexidine. J Dent Child (Chic) 2009;76(1):20-7.

8. Mohan PV, Uloopi KS, Vinay C, Rao RC. In vivo comparison of cavity disinfection efficacy with APF gel, Propolis, Diode Laser, and $2 \%$ chlorhexidine in primary teeth. Contemp Clin Dent 2016;7(1):45-50. [CrossRef]

9. Franzon R, Guimaraes LF, Magalhaes CE, Haas AN, Araujo FB. Outcomes of One-Step Incomplete and Complete Excavation in Primary Teeth: A 24-Month Randomized Controlled Trial. Caries Res 2014;48(5):376-83. [CrossRef]

10. Ersin NK, Uzel A, Aykut A, Candan U, Eronat C. Inhibition of cultivable bacteria by chlorhexidine treatment of dentin lesions treated with the ART technique. Caries Res 2006;40(2):172-7. [CrossRef]

11. Gurbuz T, Sengul F, Demirci T, Coruh M. Scanning electron microscopic analyses of the effects of different disinfection methods on dentinal structure. J Int Med Res 2013;6(2):658.

12. Turkun M, Ozata F, Uzer E, Ates M. Antimicrobial substantivity of cavity disinfectants. Gen Dent 2005;53(3):182-6.

13. Brannstrom $M$, Johnson, $G$. Effects of various conditioners and cleaning agents on prepared surfaces: a scanning electron microscopic investigation. J Prosthet Dent 1974;31:422-30. [CrossRef]

14. Zhou J, Tan J, Yang X, Cheng C, Wang X, Chen L. Effect of chlorhexidine application in a self-etching adhesive on the immediate resin-dentin bond strength. J Adhes Dent 2010;12(1):27-31.

15. Mobarak EH, El-Korashy DI, Pashley DH. Effect of chlorhexidine concentrations on micro- shear bond strength of self-etch adhesive to normal and caries-affected dentin. Am J Dent 2010;23(4):217-22.

16. Tulunoglu $\mathrm{O}$, Ayhan $\mathrm{H}$, Olmez A, Bodur $\mathrm{H}$. The effect of cavity disinfectants on microleakage in dentin bonding systems. J Clin Pediatr Dent 1998;22(4):299-305.

17. Jones CG. Chlorhexidine: is it still the gold standard? Periodontol 2000 1997;15(3):55-62. [CrossRef]

18. Twetman S, Petersson LG. Comparison of the efficacy of three different chlorhexidine preparations in decreasing the levels of mutans streptococci in saliva and interdental plaque. Caries Res 1998;32:113-8. [CrossRef]

19. Wallman C, Birkhed D. Effect of chlorhexidine varnish and gel on mutans streptococci in margins of restorations in adults. Caries Res 2002;36:360-5. [CrossRef]

20. Savas S, Kucukyilmaz E, Celik EU, Ates M. Effects of different antibacterial agents on enamel in a biofilm caries model. J Oral Sci 2015;57(4):367-72.

21. Erdem AP, Sepet E, Kulekci G, Trosola SC, Guven Y. Effects of two fluoride varnishes and one fluoride/chlorhexidine varnish on Streptococcus mutans and Streptococcus sobrinus biofilm formation in vitro. Int J Med Sci 2012;9(2):129-36. [CrossRef]

22. Jeevarathan J, Deepti A, Muthu MS, Rathna Prabhu V, Chamundeeswari GS. Effect of fluoride varnish on Streptococcus mutans counts in plaque of caries-free children using Dentocult SM strip mutans test: a randomized controlled triple blind study. J Indian Soc Pedod Prev Dent 2007;25(4):15763. [CrossRef]

23. Mei ML, Ito L, Cao Y, Li QL, Lo EC, Chu CH. Inhibitory effect of silver diamine fluoride on dentine demineralisation and collagen degradation. J Dent 2013;41:809-17. [CrossRef]

24. Bocangel JS, Kraul AOE, Vargas AG, Demarco FF, Matson E. Influence of disinfectant solutions on the tensile bond strength of a fourth generation dentin bonding agent. Pesq Odont Bras 2000;14(2):107-11. [CrossRef] 
25. Pourhajibagher M, Boluki E, Chiniforush N, Pourakbari B, Farshadzadeh Z, Ghorbanzadeh R, Aziemzadeh M, Bahador A. Modulation of virulence in Acinetobacter baumannii cells surviving photodynamic treatment with toluidine blue. Photodiagn Photodyn 2016;15:202-12. [CrossRef]

26. Williams J PGJ, Colles J, Wilson M. The antibacterial effect of TBO on bacterial colonies in a collagen matrix and carious dentine. Caries Res 2004;38:530-6. [CrossRef]

27. Zanin IC, Lobo MM, Rodrigues LK, Pimenta LA, Hofling JF, Goncalves RB. Photosensitization of in vitro biofilms by toluidine blue $\mathrm{O}$ combined with a light- emitting diode. Eur J Oral Sci 2006;114(1):64-9. [CrossRef]

28. Zanin IC, Goncalves RB, Junior AB, Hope CK, Pratten J. Susceptibility of Streptococcus mutans biofilms to photodynamic therapy: an in vitro study. J Antimicrob Chemother 2005;56(2):324-30. [CrossRef]

29. Maver-Biscanin M, Mravak-Stipetic M, Jerolimov V, Biscanin A. Fungicidal effect of diode laser irradiation in patients with denture stomatitis. Lasers Surg Med 2004;35(4):259-62. [CrossRef]

30. Turkun M, Turkun LS, Celik EU, Ates M. Bactericidal effect of Er,Cr:YSGG laser on Streptococcus mutans. Dent Mater J 2006;25(1):81-6. [CrossRef]

31. Elkassas DW, Fawzi EM, El Zohairy A. The effect of cavity disinfectants on the micro- shear bond strength of dentin adhesives. Eur J Dent 2014;8(2):184-90. [CrossRef]

32. de Mattos Pimenta Vidal C, Pavan S, Briso AL, Bedran-Russo AK. Effects of three restorative techniques in the bond strength and nanoleakage at gingival wall of Class II restorations subjected to simulated aging. Clin Oral Investig 2013;17(2):627-33. [CrossRef]

33. Chiaraputt S, Roongrujimek P, Sattabanasuk V, Panich N, Harnirattisai C, Senawongse P. Biodegradation of all-in-one selfetch adhesive systems at the resin- dentin interface. Dent Mater J 2011;30(6):814-26. [CrossRef]

34. Sano H, Takatsu T, Ciucchi B, Horner JA, Matthews WG, Pashley $\mathrm{DH}$. Nanoleakage: leakage within the hybrid layer. Oper Dent 1995;20(1):18-25.

35. Tay FR, Pashley DH, Yoshiyama M. Two modes of nanoleakage expression in single-step adhesives. J Dent Res 2002;81(7):4726. [CrossRef]

36. Oznurhan F, Olmez A. Nanoleakage in primary teeth prepared by laser irradiation or bur. Lasers Med Sci 2013;28(4):1099-105. [CrossRef]

37. Mjor IA. The location of clinically diagnosed secondary caries. Quintessence Int 1998;29(5):313-7.

38. Agrawal N, Agrawal, H., Patel, P. Effect of cavity disinfection with chlorhexidine on microleakage of composite restorations using total etch and self etch single bottle adhesive systems: an invitro study. Int J Biomed Sci 2013;2(1):43-7.

39. Mathis RS, DeWald JP, Moody CR, Ferracane JL. Marginal leakage in class $\mathrm{V}$ composite resin restorations with glass ionomer liners in vitro. J Prosthet Dent 1990;63(5):522-5. [CrossRef]

40. Sano H, Takatsu T, Ciucchi B, Horner JA, Matthews WG, Pashley $\mathrm{DH}$. Nanoleakage - Leakage within the Hybrid Layer. Oper Dent 1995;20(1):18-25.

41. Malacarne-Zanon J, de Andrade ESSM, Wang L, de Goes MF, Martins AL, Narvaes- Romani EO, Anido-Anido A, Carrilho MR. Permeability of Dental Adhesives - A SEM Assessment. Eur J Dent 2010;4(4):429-39. [CrossRef]

42. Arslan S, Yazici AR, Gorucu J, Pala K, Antonson DE, Antonson SA, Silici S. Comparison of the effects of Er,Cr:YSGG laser and different cavity disinfection agents on microleakage of current adhesives. Lasers Med Sci 2012;27(4):805-11. [CrossRef]
43. Tuzuner T, Ulusoy AT, Baygin O, Yahyaoglu G, Yalcin I, Buruk K, Nicholson J. Direct and transdentinal (indirect) antibacterial activity of commercially available dental gel formulations against Streptococcus mutans. Med Princ Pract 2013;22(4):397401. [CrossRef]

44. Moosavi H, Ahrari F, Mohamadipour $\mathrm{H}$. The effect of different surface treatments of demineralised enamel on microleakage under metal orthodontic brackets. Prog Orthod 2013;14:2. [CrossRef]

45. Selvaraj K, Sampath V, Sujatha V, Mahalaxmi S. Evaluation of microshear bond strength and nanoleakage of etch-and-rinse and self-etch adhesives to dentin pretreated with silver diamine fluoride/potassium iodide: An in vitro study. Indian J Dent Res 2016;27(4):421-5. [CrossRef]

46. Nystrom GP, Holtan JR, Olin PS, Douglas WH. Technical note: fluoride pre- treatment effects on microleakage of a resin bonding agent. Dent Mater 1989;5(5):359-60. [CrossRef]

47. Berutti E, Marini R, Angeretti A. Penetration ability of different irrigants into dentinal tubules. J Endod 1997;23(12):725-7. [CrossRef]

48. Schoop U, Kluger W, Moritz A, Nedjelik N, Georgopoulos A, Sperr W. Bactericidal effect of different laser systems in the deep layers of dentin. Lasers Surg Med 2004;35:111-6. [CrossRef]

49. Costa-Santos L, Silva-Junior ZS, Sfalcin RA, Mota A, Horliana A, Motta LJ, Mesquita- Ferrari RA, Fernandes KPS, Prates RA, Silva DFT, Deana A, Bussadori SK. The effect of antimicrobial photodynamic therapy on infected dentin in primary teeth: A randomized controlled clinical trial protocol. Medicine (Baltimore) 2019;98(15):e15110. [CrossRef]

50. Odor TM, Chandler NP, Watson TF, Ford TR, McDonald F. Laser light transmission in teeth: a study of the patterns in different species. Int Endod J 1999;32:296-302. [CrossRef]

51. Savadi Oskoee S, Alizadeh Oskoee P, Jafari Navimipour E, Ahmad Ajami A, Pournaghi Azar F, Rikhtegaran S, Amini M. Comparison of the Effect of Nd:YAG and Diode Lasers and Photodynamic Therapy on Microleakage of Class V Composite Resin Restorations. J Dent Res Dent Clin Dent Prospects 2013;7(2):7480.

52. Madani L, Sarkisians E, Kiomarsi N, Kharazifard MJ, Chiniforush N. Effect of antimicrobial photodynamic therapy on microleakage of class cavities restored with composite resin. Photodiagn Photodyn Ther 2018;23:78-82. [CrossRef]

53. Baygin O, Korkmaz FM, Arslan I. Effects of different types of adhesive systems on the microleakage of compomer restorations in Class V cavities prepared by Er,Cr:YSGG laser in primary teeth. Dent Mater J 2012;31(2):206-14. [CrossRef]

54. Gunes S, Bahsi E, Ince B, Colak H, Dalli M, Yavuz I, Sahbaz C, Cangul S. Comparative Evaluation of the Effects of Ozone, Diode Laser, and Traditional Cavity Disinfectants on Microleakage. Ozone Sci Eng 2014;36:206-11. [CrossRef]

55. Tengrungsun $T$, Smithrithee $S$, Vongsavan N, Chuckpaiwong $\mathrm{S}$, Vongsavan K. Investigation of Er : YAG laser etching on enamel-sealant interface in vitro SEM study. Lasers in Dentistry, Proceedings 2003;1248:201-8. [CrossRef]

56. Sungurtekin E, Oztas N. The effect of erbium, chromium:yttriumscandium-gallium- garnet laser etching on marginal integrity of a resin-based fissure sealant in primary teeth. Lasers Med Sci. 2010;25(6):841-7. [CrossRef] 